\title{
Nutrition of students of schools in Łódź in light of the survey
}

Odżywianie uczniów łódzkich szkół w świetle badań ankietowych

Anna Cisińska

Department of Nursing Education of the Ateliers Embodiments/Zakład Nauczania Pielęgniarstwa z Pracowniami Praktycznymi Medical University of Łódź/Uniwersytet Medyczny w Łodzi

CORRESPONDING AUTHOR/AUTOR DO KORESPONDENCJ:

Anna Cisińska

Department of Nursing Education of the Ateliers Embodiments/Zakład Nauczania Pielęgniarstwa z Pracowniami Praktycznymi Medical University of Łódź/Uniwersytet Medyczny w Łodzi

ul. Jaracza 63, 90-251 Łódź

email: anna.cisinska@umed.tódź.pl

ABSTRACT

Key words:

STRESZCZENIE

Słowa kluczowe:

\section{NUTRITION OF STUDENTS OF SCHOOLS IN RÓDŹ IN LIGHT OF THE SURVEY}

Introduction. Nutrition is vital for both human health and condition, but in a special way, it is essential for proper physical and intellectual development during adolescence. Providing the body with essential nutrients, including vitamins and trace elements also affects the functioning of a young person in a school environment. There is the energetic value of food, as well the time and frequency of its consumption, which affects the effectiveness of nutrition. At the same time, the irregularities in nutrition lead to many disorders and diseases, including overweight, obesity, anemia, anorexia.

Aim. The aim of the study was to collect information about mid-schools students and draw conclusions that might be useful for further planning of educational activities promoting health.

Material and methods. The survey questionnaire was conducted among 218 students of classes I-III selected at random. They were all students of junior high schools located in Łódź, both public and non-public ones. The analysis was conducted on the basis of anonymous questionnaires.

Results. In the study group, it was observed that the first and second breakfast was eaten by $60.5 \%$ and $42.6 \%$ of students respectively. Over $11 \%$ never ate breakfast before going to school. A high percentage of children (80\%) declared that usually they ate sandwiches.

Conclusions. Abnormalities in nutrition relate to a significant proportion of junior high school students. They often result from ignorance, haste, routines or negligence for which mostly parents are responsible. The scale of the phenomenon points to the need to implement educational activities among students and information campaigns targeted at parents, which should be carried at schools. student, nutrition, school health promotion

\section{ODŻYWIANIE UCZNIÓW RÓDZKICH SZKÓk W ŚWIETLE BADANY ANKIETOWNCH}

Wprowadzenie. Odżywianie ma kluczowe znaczenie dla zdrowia i kondycji człowieka, ale w sposób szczególny istotne jest dla prawidłowego rozwoju fizycznego i intelektualnego w okresie dojrzewania. Dostarczenie organizmowi niezbędnych substancji odżywczych, w tym witamin i mikroelementów, wpływa również na funkcjonowanie młodego człowieka w środowisku szkolnym. Obok wartości energetycznej posiłków, nie bez znaczenia dla prawidłowego przebiegu i efektywności odżywiania jest pora oraz częstotliwość ich spożywania. Równocześnie nieprawidłowości w żywieniu sprzyjają powstawaniu i rozwojowi wielu zaburzeń i chorób, m.in. nadwagi, otyłości, anemii, anoreksji.

Cel pracy. Uzyskanie informacji na temat sposobu odżywiania uczniów w wieku gimnazjalnym pod kątem jego prawidłowości oraz sformułowanie wniosków przydatnych do planowania działań edukacyjnych z zakresu promocji zdrowia.

Materiał i metodyka. Badanie przeprowadzono metodą ankietową wśród 218 uczniów losowo wytypowanych klas I-III z 2 łódzkich gimnazjów - szkoły publicznej i szkoły niepublicznej. Przedmiotem analizy były anonimowe kwestionariusze ankiet.

Wyniki. W badanej grupie zaobserwowano zachowania sprzeczne z zasadami prawidłowego odżywiania. I i ll śniadanie spożywało regularnie odpowiednio 60,5\% i 42,6\% uczniów. Ponad 11\% badanych nigdy nie zjadało śniadania przed wyjściem do szkoły. Wysoki odsetek dzieci deklarował, że najczęściej konsumowanym posiłkiem w ciągu pobytu w szkole były kanapki - 80\%.

Wnioski. Nieprawidłowości w odżywianiu dotyczą znaczącej części młodzieży gimnazjalnej. Najczęściej są one skutkiem niewiedzy, pospiechu, rutyny lub zaniedbań, za które odpowiedzialność niejednokrotnie ponoszą rodzice. Skala zjawiska wskazuje na potrzebę realizacji działań edukacyjnych wśród uczniów oraz kampanii informacyjnych, adresowanych do rodziców, których nośnikiem powinna być szkoła.

uczeń, odżywianie, szkoła, promocja zdrowia 
Let [...] parents, educators of children accustomed to moderation in food and drink

\section{INTRODUCTION}

Out of the numerous exogenous factors that influence the growth of human being, proper nutrition is mentioned as one of the most important. According to the UN's Food and Agriculture Organization (FAO) proper nutrition affects the health, productivity at work, relationship to the environment and life [1]. Poor nutrition results in abnormalities in the development of physical, motor and mental spheres. Nutrition is vital for the health and condition of a human being, but in a special way, it is essential for proper physical and intellectual development during the adolescence period. The three years-long period of study in high school is the time of important changes - psychophysical alterations start happening due to maturation.

\section{AIM}

Diagnosing the key nutritional problems that middle school students face; drawing conclusions on possible preventive measures and educational measures, facilitiating the moderation of the learning process in schools and supporting the actions related to upbringing and caring.

\section{MATERIALS AND METHODS}

The study involved 218 students (40.4\% of girls and $59.6 \%$ of boys). It was conducted in 2015 using a questionnaire distributed among 1-3 class students selected at random in two Łódź junior high schools - both public and non-public schools. The analysis was done using anonymous questionnaires. The survey included questions about eating habits, diets and sources of information about a healthy lifestyle. The questionnaires were completed independently, mainly during the classes at school. We also assessed the growth rate with BMI, calculated on the basis of the information about one's weight and height, as provided by the respondents. To interpret BMI, centile charts were used. All parents or guardians of each child gave written informed consent for a child to participate in the study. The study was approved by the Bioethics Committee of the Medical University of Łódź, the number of decision RNN/115/13/KB.

\section{RESULTS}

With the variety of findings concerning eating habits of high school students, it is particularly alarming that only $60.5 \%$ of the respondents always eat breakfast before going to school. More than $11 \%$ did not eat such a meal

Studies indicate that only $42 \%$ of respondents regularly eat lunch at school; almost $30 \%$ of students reported eating breakfast „often”, 18.3\% - „rarely”, and 8.2\% never eat any meal at school. Valuable information about the value of meals consumed at school provide answers to the question about the form of ,second breakfast" and the products that it is composed of, as illustrated in [Fig. 1].

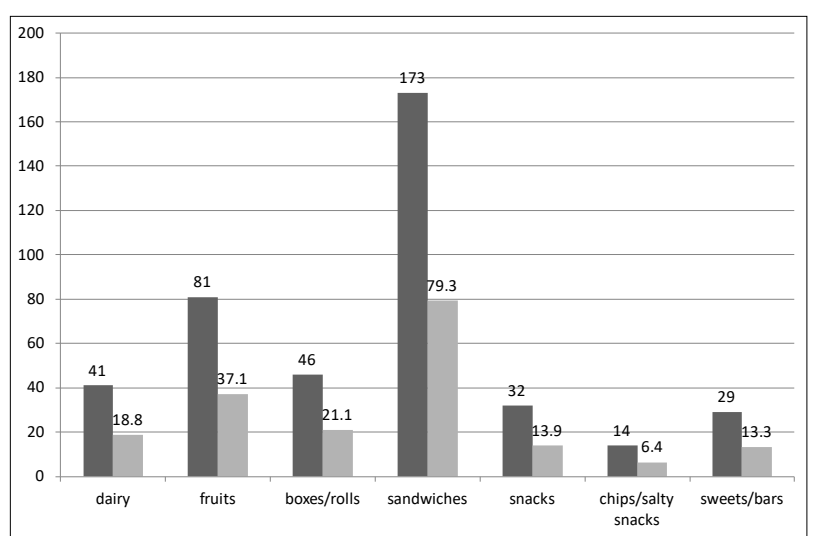

- Fig 1. "Second breakfast" at school.

Source: the author's own source

$80 \%$ of pupils eating meals at school bring sandwiches prepared at home. Every fifth student regularly eats sweet rolls and donuts, while another $13 \%$ of respondents - bars, wafers etc. An analysis of the composition of the so-called "second breakfast" - yet for many students really the "first" one - indicates other serious problems. Also, 37\% of the students admitted to eat fruits - this percentage would emphasize the word "only" because it is a highly unsatisfactory value. An almost equally large group (34.4\%) chose the complex sugars contained in donuts, sweet buns, candy bars and other sweets; although it is worth noting that buying them in school shops was made impossible due to the existing regulations. This is why the students bring sweets on their own (it is possible to buy buns that meet certain standards for sugar content). $6.4 \%$ of the students chose salty snacks regularly, especially chips. Only $18.8 \%$ of respondents mentioned the dairy products consumed as part of a school meal.

Another thing about proper nutrition is the number and regularity of meals.

The reported amounts of food eaten, as well as the frequency ( 1 or 2 meals a day), although generally exhibits a reasonable value, in case of double-digit group of students is unacceptable. It might be a signal of serious negligence on the part of the parents - it's hard to connect these with social problems that families may face (as has been verified in an interview with the teachers, exclusive phenomenon of poverty as the reason for the observed situation).

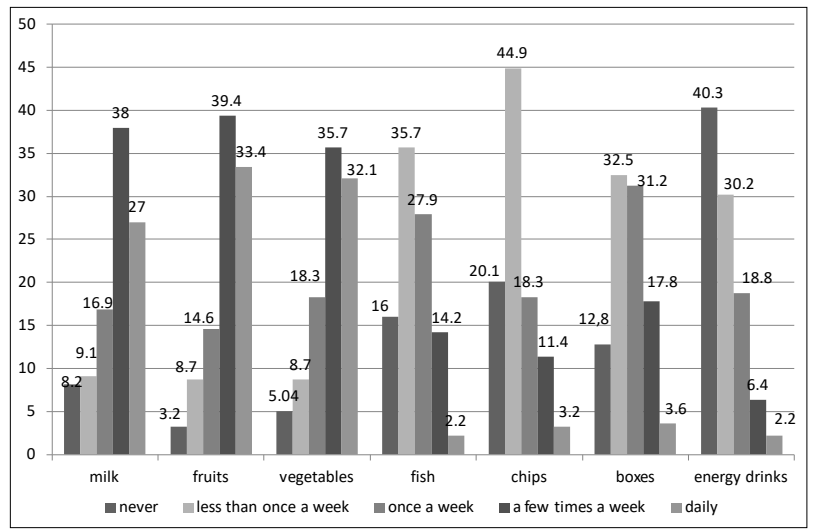

Fig 2. Frequency of consumption of each product.

Source: the author's own source 
The most important part of the daily diet of children and adolescents are products essential for proper development, to meet the needs of the young body during puberty. Respondents were asked about the frequency of consuming particular products that are easy to identify. The analysis shows that only $27 \%$ of high school students drink milk every day, and $8.2 \%$ of the students never eat. Fruits and vegetables are consumed by approximately $1 / 3$ of the respondents daily; the same amount of people eat them several times a week. The survey revealed that the menu of high school students contains no sufficient number of particularly valuable fatty acids from the omega- 3 , the source of which is fish meat. $14 \%$ of students eat fish several times a week, and $27.9 \%$ - once. In addition, $35 \%$ eat fish less than once a week, while $16 \%$ do not eat them at all.

Another element of the study was to verify the consumption of the products considered unhealthy, such as donuts, chips or energy drinks [Fig.2]. Frequency of eating them - although the overall statistical summary does not seem too high - indicates the individual problems of students who far too often reach for sweet or salty snacks. Energy drinks, when drank to excess, can be extremely dangerous and every fifth teenager admits to drink them every day or several times a week. The awareness of consumer health prevention illustrates the answer to the question of interest in the composition of consumed products. This knowledge helps eliminate the ingredients unwanted in excess, like sugar, salt or various kinds of synthetic emulsifiers, dyes, preservatives, etc from the diet. As it turns out, more than $1 / 3$ of the students never pay attention to the information on the label of a food product, and $43.1 \%$ check them „occasionally".

Lack of interest in the composition of the products consumed does not go hand in hand with ignorance about their caloric intake. More than $86 \%$ of respondents declare that they are aware of the energetic value of products, and the proportion of people using the practice of this knowledge and those who do not pay attention to the caloric content of meals is similar

Among the study group of high school students, nearly $40 \%$ of people used a diet. As reasons they suggested: the desire to slim down, physician's recommendation and cleansing of the body.

Most respondents, when asked about their lifestyle, regarded it as healthy. It is significant that middle school students mention the following sources of information on healthy lifestyle as the most important: the mass media (internet and TV - approx. 27\%, magazines - another 9.1\%), parents (approx. 20\%), and only teachers (9.6\%) and health workers (nurses, doctors $-8.5 \%$ ) respectively. The analysis of the responses is supplemented with a BMI characteristic, which may indicate how advanced the problems arising from inadequate nutrition of the respondents are. The majority of respondents reported normal weight $(60.5 \%)$. Excessive weight was reported in $4.6 \%$ of respondents, while too low weight among $17.8 \%$ of the students. Obesity was found in two students.

\section{DISCUSSION}

There are many publications both in Polish and foreign literature relating to dietary habits of children and adolescents. Proper nutrition is one of the elements of a healthy lifestyle in this age group. Eating disorders in the form of excessive weight or obesity are becoming increasingly common.

It is well known how important breakfast is for the rest of the day. Unfortunately, despite the awareness of how harmful it is not to eat breakfast, up to $15 \%$ of the population does not have breakfast at all. This percentage is increasing, particularly among children and adolescents - even every fifth student does not eat breakfast [2]. It has been observed that the incidence of obesity and insulin resistance syndrome is lower in the group of children who regularly consume breakfast [3].

When it comes to the number of meals consumed by high school students, the results are also not satisfactory. The study, which was conducted on a group of children from the Pomeranian province showed that more than one third of respondents (35.5\%) did not eat the recommended 4-6 meals per day [4]. In a study carried out by Roszko-Kirpsza et al. analyzing selected eating habits among children living in Podlaskie province it was shown that regular meals consumed $79.6 \%$ of children and $20.4 \%$ of food irregularly. In addition, a large percentage of children $(80.0 \%)$ declared consumption of four meals a day, while $2.0 \%$ of the food less than three meals a day [5]. According to the observations of other authors, only 53\% of students consumed 4-5 meals a day [6].

According to the principles developed by the Institute of Food and Nutrition for healthy nutrition of children and adolescents, dairy products should constitute the main source of calcium. They presented the results of their own studies indicating that only $27 \%$ of students drink milk every day. According to the observations of other authors, in the population of children aged 14-17 only about $1 / 5$ of young people declared drinking milk and a half of the children incldued milk in their diet only once a week or less $[7,8]$.

Fruits and vegetables are an important element in the diet of every person, and even more so in the diet of children.. Meanwhile, the consumption levels are unsatisfactory. The World Health Organization (WHO) recommends a minimum intake of 400 grams of fruit and vegetables during the day [9]. According to the dietary guidelines issued by the Institute of Food and Nutrition, fruits and vegetables should be eaten daily, several times a day (at least 5 portions a day), as part of main meals or between them. The latest scientific reports postulated that it is best to consume 7 portions of fruits and vegetables daily [10].

Studies have shown that a diet rich in fruits and vegetables plays an important role in the preventing many diseases, including cardiovascular problems and cancer, as well as preventing other non-communicable diseases, such as hypertension, diabetes, obesity $[11,12]$. According to a report by the National Institute of Public Health - National Institute of Hygiene it shows that Poland takes the 
second place in terms of the amount of intake of fruits and vegetables to other countries in the European Union [13].

The results of research conducted among 380 high school students from Warsaw showed that $35.8 \%$ do not eat fruits or vegetables at all [14]. The report prepared by the Institute of Mother and Child shows that only one out of six 13-year-olds eats fruits 2 times a day or more often. In turn, every seventh respondent eats fruits at most once a week or even less. Rating the frequency of vegetable consumption has shown that almost $90 \%$ of 13 -year-olds eat vegetables at most 1 time a day, and only every tenth day, 2 times a week or more [15].

The fact that an increasing number of children and young people reach for sweet sodas and energy drinks is particularly alarming. During the last decade, the consumption of sugary drinks, which are the source of simple sugars, increased by approximately $40 \%$ [16]. Numerous studies conducted among high school students related to the consumption of beverages among this group noticed that almost every second child is drinking sweetened beverages at least once a day [17]. A similar situation exists when it comes to energy drinks, the consumption of which is constantly growing since 1995, when they first appeared on the Polish market. A study conducted among high school students from the area of the three provinces of Mazovia, Podlasie and Łódź showed that the so-called. measures for food for special purposes is chosen by $17 \%$ junior high school students and $24 \%$ of secondary schools [18].

The fact that high school students go on different diets, without any healthcare specialist's supervision, is another factor influencing poor nutrition Research conducted in two centers (British and American) confirmed that the use of diet by young people is a factor predisposing to obesity [19].

\section{CONCLUSIONS}

Although the relationship between proper nutrition and health condition is quite obvious and generally uncontested, the practice in this field does not always keep up with the theory, which consists of the recommendations of doctors and nutritionists, educational content included within the current school core curriculum, campaigns healthy eating, as well as the popularization of scientific research in the field of medical science and related disciplines. As it is clear from the statements of teenage respondents eating habits do not seem to take into account fully the principles of proper nutrition. This mainly concerns the quality of meals, and subsequently - their volume per day, the energy and frequency. Being constantly in a state of rush, even during meals, is another factor that potentially affects metabolic balance.

\section{Odżywianie uczniów łódzkich szkół w świetle badań ankietowych}

Let [...] parents, educators of children accustomed to moderation in food and drink

\section{A. F. Modrzewski}

\section{WPROWADZENIE}

Spośród wielu czynników egzogennych, wpływających na rozwój człowieka, w pierwszym rzędzie wymieniane jest żywienie. Według Organizacji Narodów Zjednoczonych do spraw Wyżywienia i Rolnictwa (FAO) właściwe żywienie determinuje stan zdrowia, produktywność w pracy, stosunek do otoczenia i życia [1]. Nieprawidłowe odżywianie skutkuje zaburzeniami w rozwoju fizycznym, motorycznym i psychicznym. Odżywianie ma kluczowe znaczenie dla zdrowia i kondycji człowieka, ale w sposób szczególny istotne jest dla prawidłowego rozwoju fizycznego i intelektualnego w okresie dojrzewania. Na trzyletni okres nauki w gimnazjum przypada czas ważnych przemian psychofizycznych i swoiste apogeum procesu dojrzewania.

\section{CEL PRACY}

Zdiagnozowanie głównych problemów w obszarze odżywiania młodzieży w wieku gimnazjalnym; sformułowanie wniosków na temat możliwych działań prewencyjnych, profilaktycznych i edukacyjnych, wspomagających moderowanie procesu kształcenia w szkołach oraz wspierających merytorycznie działania wychowawczo-opiekuńcze rodziców.

\section{MATERIAŁ I METODYKA}

W badaniu wzięło udział 218 uczniów (40,4\% dziewcząt i 59,6\% chłopców). Badanie przeprowadzono w 2015 roku metodą ankietową wśród uczniów losowo wytypowanych klas I-III z 2 łódzkich gimnazjów - szkoły publicznej i szkoły niepublicznej. Przedmiotem analizy były anonimowe kwestionariusze ankiet. Na przeprowadzenie badania uzyskano zgodę Komisji Bioetycznej Uniwersytetu Medycznego w Łodzi numer decyzji RNN/115/13/KB.

\section{WYNIKI}

Wśród wielu ustaleń, opisujących nawyki żywieniowe gimnazjalistów, szczególnie alarmujący jest fakt, że tylko $60,5 \%$ badanych przed wyjściem do szkoły zawsze spożywa śniadanie. Ponad $11 \%$ nigdy takiego posiłku nie zjada. Badania wskazały, że tylko $42 \%$ respondentów regularnie spożywa drugie śniadanie w szkole; prawie 30\% uczniów deklarowało, że je śniadanie „często”, 18,3\% - „rzadko”, a 8,2\% nigdy nie spożywa w szkole opisywanego posiłku. Cennych informacji o wartości posiłków spożywanych w szkole dostarczają odpowiedzi na pytanie o formę „drugich śniadań” i produkty, które wchodzą w ich skład, co obrazuje [ryc. 1]. 


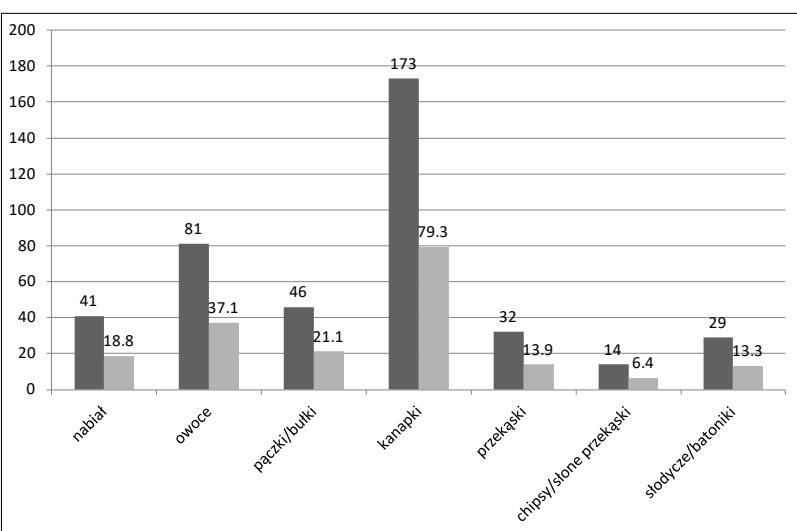

- Ryc 1. „Drugie śniadanie” w szkole.

Źródło: opracowanie własne

80\% uczniów spożywających posiłki w szkole przynosi ze sobą kanapki przygotowane w domu. Co piąty uczeń systematycznie jada słodkie bułki i pączki, zaś kolejne 13\% respondentów - batoniki, wafelki itp. Analizując skład tzw. „drugich śniadań” - choć dla wielu uczniów tak naprawdę pierwszych - należy wskazać na kolejne poważne problemy. Do spożywania owoców przyznało się 37\% uczniów - odsetek ten należałoby podkreślić słowem „zaledwie”, gdyż jest to wskaźnik wysoce niesatysfakcjonujący. Niemal równie liczna grupa $(34,4 \%)$ wybrała cukry złożone, zawarte w pączkach, słodkich bułkach, batonikach i innych słodyczach; warto podkreślić, że w świetle do niedawna obowiązujących regulacji nabycie tego typu produktów w szkolnych sklepikach było niemożliwe, a zatem uczniowie przynosili słodycze ze sobą (obecnie dopuszczona jest sprzedaż drożdżówek spełniających określone normy zawartości cukru). 6,4\% uczniów wybierało regularnie słone przekąski, przede wszystkim chipsy. Tylko 18,8\% badanych wymieniło nabiał jako składnik spożywanego w szkole posiłku.

Poruszając temat prawidłowego odżywiania, należy zwrócić uwagę na liczbę i regularność posiłków. Ilość i częstotliwość spożywania posiłków - choć generalnie wykazuje rozsądne wartości - w przypadku kilkunastoprocentowej grupy uczniów pozostaje nieakceptowalna - na poziomie 1 lub 2 posiłków dziennie. Jest to szczególnie alarmujący sygnał poważnych zaniedbań ze strony rodziców - trudno te odpowiedzi łączyć z problemami socjalnymi rodzin (co zostało zweryfikowane w wywiadzie z pedagogami, wykluczającymi zjawisko ubóstwa jako powód zaobserwowanej sytuacji).

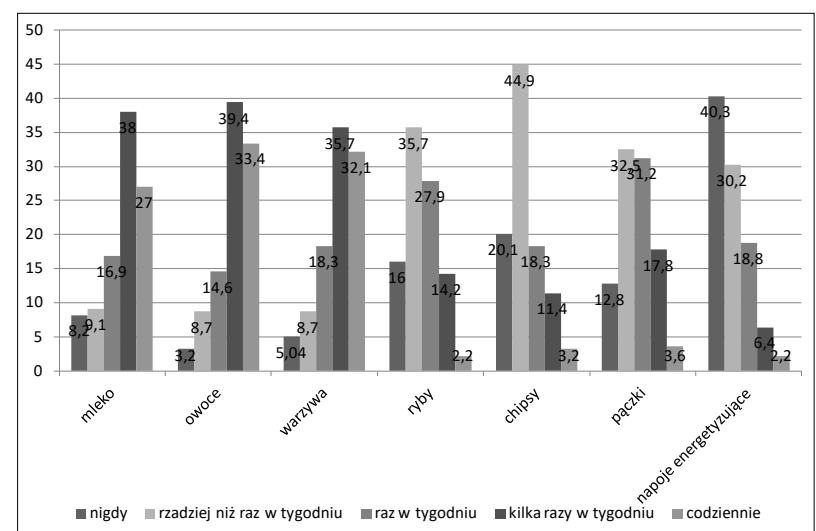

Ryc 2. Częstotliwość spożywania poszczególnych produktów. Źródło: opracowanie własne
Najważniejszy element codziennej diety dzieci i młodzieży stanowią produkty niezbędne do prawidłowego rozwoju, odpowiadające potrzebom młodego organizmu w okresie dojrzewania. Respondentów zapytano o częstotliwość spożywania poszczególnych produktów, łatwych do zidentyfikowania. Z przeprowadzonej analizy wynika, że tylko $27 \%$ badanych gimnazjalistów pije codziennie mleko, zaś $8,2 \%$ uczniów nigdy go nie spożywa. Owoce i warzywa są konsumowane codziennie przez około $1 / 3$ badanych; tyle samo osób jada je kilka razy w tygodniu. Niepokojący wydaje się fakt, że pozostali uczniowie sięgają po owoce i warzywa raz w tygodniu lub rzadziej; pojedyncze osoby przyznały, że nigdy nie spożywają tego typu żywności, co wydaje się wręcz nieprawdopodobne.

$\mathrm{Z}$ ankiety wynika, że w menu gimnazjalistów występuje zbyt mała ilość szczególnie wartościowych kwasów tłuszczowych z grupy omega-3, których źródłem jest mięso ryb. $14 \%$ uczniów je ryby kilka razy w tygodniu, a 27,9\% - raz. Aż 35\% opisywanej grupy spożywa ryby rzadziej niż raz w tygodniu, natomiast $16 \%$ nie je ich w ogóle.

Kolejnym elementem badania była weryfikacja spożywania produktów uważanych za niezdrowe, takich jak: pączki, chipsy, napoje energetyzujące [ryc.2]. Częstotliwość ich spożywania - choć w ogólnym zestawieniu statystycznym nie wydaje się zbyt duża - wskazuje na indywidualne problemy uczniów, którzy zdecydowanie zbyt często sięgają po słodkie lub słone przekąski. Wyjątkowo niebezpieczne może być nadużywanie napojów energetyzujących, które pije - codziennie lub kilka razy w tygodniu - co piąty nastolatek.

Świadomość prozdrowotną i konsumencką młodych ludzi obrazują odpowiedzi na pytanie o zainteresowanie składem spożywanych produktów. Jak wiadomo, wiedza ta pozwala eliminować $\mathrm{z}$ diety składniki w nadmiarze niepożądane, jak chociażby cukier, sól czy różnego rodzaju syntetyczne emulgatory, barwniki, konserwanty itp. Okazuje się, ponad 1/3 uczniów nigdy nie zwraca uwagi na informacje umieszczone na etykiecie produktu spożywczego, zaś 43,1\% sprawdza je „sporadycznie”.

Brak większego zainteresowania składem spożywanych produktów nie idzie w parze $\mathrm{z}$ niewiedzą na temat ich kaloryczności. Ponad $86 \%$ badanych deklaruje, że posiada wiedzę na temat wartości energetycznej produktów, przy czym odsetek osób korzystających w praktyce $\mathrm{z}$ tej wiedzy oraz osób, które nie zwracają uwagi na kaloryczność posiłków, jest wyrównany.

Wśród badanej grupy gimnazjalistów prawie $40 \%$ osób stosowało dietę. Jako powód wymieniali: chęć odchudzenia, zalecenia lekarza oraz oczyszczenie organizmu.

Większość respondentów, odpowiadając na pytanie dotyczące trybu życia, określało go mianem zdrowego. Znamienne, że głównym źródłem informacji na temat zdrowego trybu życia są dla gimnazjalistów kolejno: środki masowego przekazu (Internet i telewizja - ok. 27\%, czasopisma - kolejne 9,1\%), rodzice (ok. 20\%), a następnie dopiero nauczyciele $(9,6 \%)$ i pracownicy ochrony zdrowia (pielęgniarki, lekarze - 8,5\%).

Uzupełnieniem analizy odpowiedzi jest charakterystyka BMI, która może wskazywać, na ile zaawansowane są problemy, wynikające $\mathrm{z}$ nieprawidłowego odżywiania 
respondentów. Większość badanych charakteryzowała się prawidłową masą ciała (60,5\%). Nadwagę stwierdzono u 4,6\% badanych, natomiast niedowagę wśród 17,8\% uczniów. Otyłość stwierdzono u dwóch uczniów.

\section{DYSKUSJA}

W piśmiennictwie polskim i zagranicznym jest wiele publikacji dotyczących nawyków żywieniowych wśród dzieci i młodzieży. Prawidłowe odżywianie stanowi jeden z elementów prozdrowotnego stylu życia w tej grupie wiekowej. Coraz częściej spotyka się zaburzenia odżywiania w postaci nadmiernej masy ciała czy otyłości.

Powszechnie wiadomo, jak ważnym posiłkiem w ciągu dnia jest śniadanie. Niestety, mimo świadomości, która nie jest jedynie domeną specjalistów, aż 15\% społeczeństwa nie spożywa śniadania w ogóle. Odsetek ten wzrasta szczególnie wśród dzieci i młodzieży - nawet co piąty uczeń nie je śniadania [2]. Zaobserwowano, że częstotliwość występowania otyłości i zespołu insulinooporności jest niższa w grupie dzieci, które spożywają regularnie śniadanie [3].

Jeśli chodzi o liczbę posiłków spożywanych przez młodzież gimnazjalną to wyniki również nie są zadawalające. Badania, które były prowadzone na grupie dzieci z województwa pomorskiego wykazały, że ponad jedna trzecia badanych $(35,5 \%)$ nie spożywało zalecanych 4-6 posiłków dziennie [4]. W badaniach zrealizowanych przez Roszko-Kirpsza i wsp. analizujących wybrane nawyki żywieniowe wśród dzieci województwa podlaskiego wykazano, że regularne posiłki spożywało 79,6\% dzieci, zaś $20,4 \%$ jadło nieregularnie. Ponadto duży odsetek dzieci $(80,0 \%)$ deklarowało spożycie czterech posiłków w ciągu dnia, zaś 2,0\% badanych jadło mniej niż trzy posiłki dziennie [5]. Według obserwacji innych autorów jedynie 53\% uczniów konsumowało 4-5 posiłków dziennie [6].

Według opracowanych przez Instytut Żywności i Żywienia zasad zdrowego żywienia dzieci i młodzieży w diecie najmłodszych powinny znajdować się produkty mleczne stanowiące główne źródło wapnia. Prezentowane własne wyniki badań wskazują, że tylko 27 \% uczniów pije mleko codziennie. Według obserwacji innych autorów w populacji dzieci w wieku 14-17 lat codzienne picie mleka deklarowało jedynie około 1/5 młodzieży, a połowa dzieci włączała do swojej diety mleko i napoje mleczne tylko raz w tygodniu lub rzadziej $[7,8]$.

Istotnym elementem w diecie każdego człowieka, a tym bardziej w diecie dzieci powinny stanowić warzywa i owoce jako źródło witamin i mikroelementów. Tymczasem spożycie wspomnianych produktów jest niezadowalające. Światowa Organizacja Zdrowia (WHO) zaleca spożycie minimum 400 g warzyw i owoców w ciągu dnia [9]. Według zaleceń żywieniowych Instytutu Żywności i Żywienia, warzywa i owoce powinny być spożywane codziennie kilka razy dziennie (co najmniej 5 porcji dziennie) w ramach głównych posiłków oraz między nimi. Najnowsze doniesienia naukowe postulują, że najlepiej spożywać codziennie 7 porcji warzyw i owoców [10].

Badania dowiodły, że dieta bogata w owoce i warzywa odgrywa ważną rolę w prewencji wielu chorób, m.in. schorzeń układu krążenia i nowotworów, a także zapobiega innym chorobom niezakaźnym, takich jak: nadciśnienie, cukrzyca, otyłość $[11,12]$. Według raportu przygotowanego przez Narodowy Instytut Zdrowia Publicznego - Państwowy Zakład Higieny wynika, że Polska zajmuje przedostatnie miejsce pod względem ilości spożywanych warzyw i owoców na tle innych krajów Unii Europejskiej [13].

Wyniki badań przeprowadzone wśród 380 uczniów szkół warszawskich wykazały, że warzywa i owoce nie są spożywane przez 35,8\% uczniów [14]. Z raportu opracowanego przez Instytut Matki i Dziecka wynika, że tylko co szósty 13-latek spożywa owoce 2 razy dziennie lub częściej. Z kolei co siódmy badany zjada owoce najwyżej 1 raz w tygodniu lub rzadziej. Ocena częstości spożywania warzyw wykazała, że prawie 90\% 13-latków zjada warzywa najwyżej 1 raz dziennie, a tylko co dziesiąty codziennie, 2 razy w tygodniu lub częściej [15].

Niepokoić może fakt, że coraz częściej dzieci i młodzież sięgają po słodkie napoje gazowane i energetyzujące. W ostatniej dekadzie spożycie napojów słodkich, które są źródłem cukrów prostych, zwiększyło się o około $40 \%$ [16]. Z licznych badań prowadzonych wśród uczniów szkół dotyczących spożywania napojów wśród tej grupy zauważono, że niemal co drugie dziecko pije napoje słodzone co najmniej raz dziennie [17]. Podobnie sytuacja przedstawia się jeśli chodzi o napoje energetyzujące, których konsumpcja stale rośnie począwszy od roku 1995, kiedy to po raz pierwszy trafiły na polski rynek. Badania przeprowadzone wśród uczniów szkół z terenu trzech województw mazowieckiego, łódzkiego i podlaskiego wykazały, że po tzw. środki specjalnego przeznaczenia żywieniowego sięga odpowiednio 17\% uczniów szkół gimnazjalnych i 24\% ze szkół ponadgimnazjalnych [18].

Kolejnym aspektem złego odżywiania jest stosowanie wśród gimnazjalistów różnego rodzaju diet - bez nadzoru pracownika opieki zdrowotnej. Badania prowadzone w dwóch ośrodkach (brytyjskim i amerykańskim) potwierdziły, że stosowanie diet przez młodzież jest czynnikiem predysponującym do występowania otyłości. [19].

Aby takie kształcenie było możliwe potrzebne są działania zmierzające do poznania punktu wyjściowego oraz motywacji podejmowania kształcenia.

\section{WNIOSKI}

Mimo, że zależność między prawidłowym odżywianiem a kondycją zdrowotną jest dość oczywista i na ogół niekwestionowana, praktyka w omawianym zakresie nie zawsze nadąża za teorią, na którą składają się zalecenia lekarzy i dietetyków, treści kształcenia ujęte w ramach obowiązującej w szkołach podstawy programowej, kampanie promujące zdrowe odżywianie, a także popularyzacja badań naukowych $\mathrm{z}$ dziedziny nauk medycznych i pokrewnych dyscyplin. Jak wynika $z$ wypowiedzi nastoletnich respondentów, nawyki żywieniowe zdają się nie uwzględniać w pełni zasad prawidłowego odżywiania. Dotyczy to przede wszystkim jakości posiłków, a w dalszej kolejności - ich ilości w skali doby, wartości energetycznej oraz częstotliwości. Czynnikiem potencjalnie zaburzającym równowagę metaboliczną może być również pośpiech, często towarzyszący jedzeniu. 


\section{PIŚMIENNICTWO/REFERENCES}

1. Dziankowska-Zaborszczyk E, i wsp. Zachowania zdrowotne związane z żywieniem a ryzyko zgonu mieszkańców Łodzi w wieku 18-64lat w obserwacji ośmioletniej. Prob Hig Epidemiol. 2014; 95 (2):358-365.

2. Wądołowska L i wsp. Śniadanie i jego znaczenia dla naszego zdrowia. Warszawa; 2013: 3-49.

3. Chęcińska Z i wsp. Ocena sposobu żywienia młodzieży wielkomiejskiej i obszarów wiejskich. Prob Hig Epidemiol. 2013; 94 (4):780-785.

4. Pieszko-Klejnowska M i wsp. Ocena sposobu odżywiania się gimnazjalnej młodzieży zamieszkującej wieś i miasto. Pediatr Współcz. 2007; 9:59-62.

5. Roszko-Kirpsza I i wsp. Wybrane nawyki żywieniowe a stan odżywienia dzieci i młodzieży regionu Podlasia, Prob Hig Epidemiol. 2011; 92 (4):799-805.

6. Wojtyła-Buciora P i wsp. Sposób żywienia uczniów szkół podstawowych w powiecie kaliskim- w opinii dzieci i ich rodziców. Probl Hig Epidemiol. 2015; 96(1):245-253.

7. Lange E i wsp. Skład ciała i wybrane nawyki żywieniowe dzieci w wieku 14-17 lat, Bromat.Chem.Toksykol. 2011; 3:389-397.

8. Wojtyła-Buciora Pi wsp. Sposób żywienia uczniów szkół podstawowych w powiecie kaliskim- w opinii dzieci i ich rodziców. Probl Hig Epidemiol. 2015; 96(1):245-253.

9. Wolnicka K, Jaczewska-Schuetz J. Stan odżywienia a nawyki żywieniowe wśród dzieci w wieku szkolnym z Warszawy. Post Nauk Medycznych. 2011; 24 (9):724-731.

10. Polacy jedzą za mało warzyw i owoców. http://www.izz.waw.pl/; (6.09. 2016).
11. Trine $P$, Charlotte $M, B j ø r n E$ et al. Fruit and vegetable intake is associated with frequency of breakfast, lunch and evening meal: cross-sectional study of 11-, 13and 15-year-olds. Int J Behav Nutr Phys Act. 2012; 9:1-10.

12. Raport IASO/IOTF. www.iaso.org (10.08.2016).

13. Wojtyniak B, Goryński P. Sytuacja zdrowotna ludności Polski. Warszawa: Narodowy Instytut Zdrowia Publicznego - Państwowy Zakład Higieny. 2008, s.1-16.

14. Wolnicka K, Jaczewska-Schuetz J, Taraszewska A. Analiza czynników wpływających na spożycie warzyw i owoców przez dzieci w wieku szkolnym. Probl Hig Epidemiol. 2014, 95 (2):389-393

15. Mikiel-Kostyra K, Oblacińska A. Czynniki biologiczne, behawioralne psychospołeczne kształtujące masę ciała (BMI) 13-latków, IMiD. Warszawa; 2010: 5-184.

16. Cisek M, Martko H i wsp. Ocena sposobu żywienia uczniów w Zubrzycy Górnej, Żyw. Człow. Metab. 2007, 34: 595-561.

17. Sosnowska-Bielicz E, Wrótniak J. Nawyki żywieniowe a otyłość dzieci w wieku przedszkolnym i szkolnym. Lubelski Rocznik Pedagogiczny. 2013; 32:147-165.

18. Błaszczyk E, Piórecka B. i wsp. Konsumpcja napojów energetyzujących i zachowania z nią związane wśród młodzieży wiejskiej. Probl Hig Epidemiol. 2013; 94 (4):815-819.

19. Wojtyła A, Biliński A. i wsp. Zaburzenia odżywiania u polskich gimnazjalistów. Prob Hig Epidemiol. 2011; 92 (2):343-350.

Praca przyjęta do druku/Manuscript received:

15.07.2016

Praca zaakceptowana do druku/Manuscript accepted: 22.11.2016

Tłumaczenie/Translation: M. Conio 